\title{
Effect of Cow Based Bio-enhancers and Botanicals on Growth and Yield of Soybean (Glycine max L.)
}

\author{
Pooja $^{1 *}$, P. K. Chovatia ${ }^{1}$, R. K. Kathiriya ${ }^{1}$ and Khushboo Gupta ${ }^{2}$ \\ ${ }^{1}$ Department of Agronomy, College of Agriculture, Junagadh Agricultural University, \\ Junagadh, 362 001, Gujarat, India \\ ${ }^{2}$ Department of Plant Physiology, Institute of Agri. Sciences, Banaras Hindu University, \\ Varanasi-221 005, Uttar Pradesh, India \\ *Corresponding author
}

\section{A B S T R A C T}

\section{Keywords}

Soybean,

Panchgavya,

Banana pseudostem

sap, Seaweed

extract, Organic

farming

\section{Article Info}

Accepted:

04 August 2020

Available Online:

10 September 2020
A field experiment was conducted at Instructional Farm, Junagadh Agricultural University, Junagadh, Gujarat, during the year 2018 and 2019 on medium black calcareous clayey soil to study the effect of some cow based bio-enhancers and botanicals on growth and yield of soybean. The variety which was taken in the experiment was GJS-3. The experiment was designed in randomized block design having treatments Control $\left(\mathrm{T}_{1}\right), 100 \%$ RDF $\left(\mathrm{T}_{2}\right)$ (outside the organic plot), FYM @ 10 t/ha ( $\left.\mathrm{T}_{3}\right), \mathrm{FYM} @ 5 \mathrm{t} / \mathrm{ha}+$ Panchgavya @ 3\% as foliar spray at 30 and 60 DAS $\left(\mathrm{T}_{4}\right)$, FYM @ 5 t/ha + Banana Pseudostem sap @ 1\% as foliar spray at 30 and 60 DAS $\left(\mathrm{T}_{5}\right)$, FYM @ 5 t/ha + Seaweed extract @ 3.5\% as foliar spray at 30 and 60 DAS $\left(\mathrm{T}_{6}\right)$, FYM @ $5 \mathrm{t} / \mathrm{ha}+$ Cow urine @ 3\% as foliar spray at 30 and 60 DAS $\left(\mathrm{T}_{7}\right)$, Vermicompost @ $4 \mathrm{t} / \mathrm{ha}\left(\mathrm{T}_{8}\right)$, Vermicompost @ $2 \mathrm{t} / \mathrm{ha}+$ Panchgavya @ 3\% as foliar spray at 30 and 60 DAS $\left(\mathrm{T}_{9}\right)$, Vermicompost @ $2 \mathrm{t} / \mathrm{ha}+$ Banana Pseudostem sap @ $1 \%$ as foliar spray at 30 and $60 \mathrm{DAS}\left(\mathrm{T}_{10}\right)$, Vermicompost @ $2 \mathrm{t} / \mathrm{ha}+$ Seaweed extract @ 3.5\% as foliar spray at 30 and 60 DAS $\left(\mathrm{T}_{11}\right)$ and Vermicompost @ $2 \mathrm{t} / \mathrm{ha}+$ Cow urine @ 3\% as foliar spray at 30 and 60 DAS $\left(\mathrm{T}_{12}\right)$ produced comparable results regarding growth (plant height, number of leaves and number of nodules per plant) and yield of soybean. Experiment result reported that during organic cultivation of soybean, application of Vermicompost @ $4 \mathrm{t} /$ ha performed better results which was significantly at par with treatments FYM@10 t/ha, Vermicompost 2 t/ha +Panchgavya @ 3\% as foliar spray at 30 and 60 DAS and FYM @ 5 t/ha + Panchgavya @ 3\% as foliar spray at 30 and 60 DAS.

\section{Introduction}

Soybean (Glycine $\max$ L.) is the most important oilseed crop among all the oilseed crops of world. It is extremely resilient and performs good even under severe water stress conditions. It has quality to improve soil fertility by fixing atmospheric nitrogen to the extent of $50-60 \mathrm{~kg} / \mathrm{ha}$, depending on the agroclimatic conditions, variety, strains, etc. soybean is well known for its nutritional and health benefits. It contains about $40 \%$ good quality protein, $20 \%$ oil having about $85 \%$ unsaturated fatty acids including $55 \%$ 
polyunsaturated fatty acids (PUFA), 20-25\% carbohydrates and almost no starch, 4-5\% minerals, anti-oxidants and $2 \%$ phospholipids (Halwankar et al., 1992). It has a very high potential among grain legume crops for combating acute malnutrition. Soybean protein is mainly rich in amino acids like lysine, leucine, methionine and threonine. For vegetarians, it is known as "poor man's meat". Because of the absence of sugar content, it is very much suitable diet for diabetic patients. With the continuous use of inorganic fertilizer it deteriorates the soil health in respect of physical, chemical and biological properties of soil. Therefore, it is necessary to minimize the application of inorganic fertilizers by substituting with organics. However, over dependency on chemical farming has led to deterioration of soil health resulted in decline in productivity, besides causing soil and water pollution problems and health hazards (Pandey et al., 2008). The use of organic liquid such as Panchgavya and Jivamrut results in higher growth, yield, and quality of crops. Panchgavya is an efficient plant growth stimulant that enhanced the yield and improved biological efficiency of the crop (Gore and Sreenivasa, 2011). Banana pseudostem sap and seaweed extract have been recommended by agricultural institutions. Use of both the substances increase nutrient uptake from the soil and enhance antioxidant properties, they help in improve the growth and development of plants. Cow urine is a good source of nitrogen to plant growth however its excess application to soil needs monitoring to avoid salinity and its effect on soil microflora.

\section{Materials and Methods}

A field trial was laid out in a randomized block design during 2018 and 2019 at Instructional Farm, Junagadh Agricultural University, Junagadh (Gujarat). The experimental soil was medium black calcareous clayey with medium in organic carbon and slightly alkaline ( $\mathrm{pH} 8.1$ and 7.7). The available $\mathrm{N}$ was low, $\mathrm{P}_{2} \mathrm{O}_{5}$ and $\mathrm{K}_{2} \mathrm{O}$ content of soil were medium. The total treatment combinations were twelve and replicated thrice involved main plot treatment consisted with combination of two fertility gradients, i.e. Control $\left(\mathrm{T}_{1}\right), 100 \% \mathrm{RDF}\left(\mathrm{T}_{2}\right)$ (outside the organic plot), FYM @ 10 t/ha $\left(\mathrm{T}_{3}\right), \mathrm{FYM} @ 5 \mathrm{t} / \mathrm{ha}+$ Panchgavya@3\% as foliar spray at 30 and 60 DAS $\left(\mathrm{T}_{4}\right)$, FYM @ 5 t/ha + Banana Pseudostem sap @1\% as foliar spray at 30 and 60 DAS $\left(\mathrm{T}_{5}\right)$, FYM @ 5 t/ha + Seaweed extract@3.5\% as foliar spray at 30 and 60 DAS $\left(\mathrm{T}_{6}\right), \mathrm{FYM} @ 5$ t/ha + Cow urine @ 3\% as foliar spray at 30 and 60 DAS $\left(\mathrm{T}_{7}\right)$, Vermicompost @ $4 \mathrm{t} / \mathrm{ha}\left(\mathrm{T}_{8}\right)$, Vermicompost @ 2 t/ha + Panchgavya @ 3\% as foliar spray at 30 and 60 DAS ( $\left.\mathrm{T}_{9}\right)$, Vermicompost @ 2 t/ha + Banana Pseudostem sap @ 1\% as foliar spray at 30 and 60 DAS $\left(\mathrm{T}_{10}\right)$, Vermicompost @ 2 t/ha + Seaweed extract @ 3.5\% as foliar spray at 30 and 60 DAS $\left(\mathrm{T}_{11}\right)$ and Vermicompost@2 t/ha + Cow urine@3\% as foliar spray at 30 and 60 DAS $\left(\mathrm{T}_{12}\right)$. A seed rate of $60.00 \mathrm{~kg} / \mathrm{ha}$ of variety 'GJS-3' was used for the experiment at a row spacing of 45 $\mathrm{cm}$ and plant to plant at a distance of $10 \mathrm{~cm}$ to maintain plant geometry of $45 \times 10 \mathrm{~cm}^{2}$. No any kind of herbicide were used to control the weeds, this was done by manual weeding two times during the season. To maintain optimum soil moisture need based irrigation were applied for plant growth. Panchgavya was prepared at Instructional farm by using nine ingredients.

\section{Results and Discussion}

\section{Effect on Plant height and number of leaves per plant}

Data (Table 1) on plant height revealed that the cow based bio-enhancers and botanicals caused significant effect on plant height at 60 
DAS. The highest plant height $(47.78 \mathrm{~cm})$ was recorded under $100 \% \mathrm{RDF}\left(\mathrm{T}_{2}\right)$ in pooled results, which remained statistically at par with treatments Vermicompost @ 4 t/ha $\left(\mathrm{T}_{8}\right)$ and FYM @ 10 t/ha $\left(\mathrm{T}_{3}\right)$. However, the lowest plant height $(37.46 \mathrm{~cm})$ was registered under the control $\left(\mathrm{T}_{1}\right)$.

Data showed (Table 1) that different treatments exerted their significant effect on number of leaves per plant at 30 DAS and 60
DAS. The maximum number of leaves per plant (35.68) was recorded with application of $100 \%$ RDF $\left(\mathrm{T}_{2}\right)$ which was found statistically at par with Vermicompost @ 4 t/ha $\left(\mathrm{T}_{8}\right)$, FYM @ $10 \mathrm{t} / \mathrm{ha}\left(\mathrm{T}_{3}\right)$, Vermicompost @ $2 \mathrm{t} / \mathrm{ha}$ +Panchgavya as foliar spray @ 3\% at 30 and 60 DAS $\left(\mathrm{T}_{9}\right)$ and FYM @ 5 t/ha + Panchgavya as foliar spray @ 3\% at 30 and 60 DAS $\left(\mathrm{T}_{4}\right)$. And minimum number of leaves per plant (27.48) was registered under the control $\left(\mathrm{T}_{1}\right)$.

Table.1 Effect of different treatments on plant height, number of leaves per plant, number of nodules per plant and seed yield of soybean

\begin{tabular}{|c|c|c|c|c|c|c|c|}
\hline \multirow[t]{2}{*}{ Treatment } & \multicolumn{2}{|c|}{ Plant height $(\mathrm{cm})$} & \multicolumn{2}{|c|}{ No. of leaves/plant } & \multicolumn{2}{|c|}{ No. of nodules/plant } & \multirow{2}{*}{$\begin{array}{l}\text { Seed Yield } \\
\text { (kg/ha) }\end{array}$} \\
\hline & 30 DAS & 60 DAS & 30 DAS & 60 DAS & 30 DAS & 60 DAS & \\
\hline $\mathbf{T}_{1}$ & 19.29 & 37.46 & 8.98 & 27.48 & 18.08 & 34.28 & 1398 \\
\hline $\mathbf{T}_{2}$ & 24.72 & 47.78 & 14.58 & 35.68 & 28.07 & 50.20 & 2509 \\
\hline $\mathbf{T}_{\mathbf{3}}$ & 23.59 & 44.44 & 13.95 & 33.60 & 28.27 & 51.13 & 2370 \\
\hline $\mathbf{T}_{4}$ & 22.76 & 42.31 & 12.72 & 33.03 & 24.63 & 45.05 & 2324 \\
\hline $\mathbf{T}_{5}$ & 21.62 & 41.16 & 11.98 & 31.10 & 24.12 & 44.73 & 1935 \\
\hline $\mathbf{T}_{6}$ & 21.45 & 38.46 & 11.32 & 30.13 & 24.02 & 44.05 & 1852 \\
\hline $\mathbf{T}_{7}$ & 22.32 & 41.39 & 12.15 & 31.60 & 24.38 & 44.88 & 2065 \\
\hline $\mathbf{T}_{8}$ & 23.82 & 46.37 & 14.13 & 33.92 & 28.77 & 52.33 & 2463 \\
\hline $\mathbf{T}_{9}$ & 23.53 & 42.96 & 13.48 & 33.07 & 25.33 & 48.12 & 2333 \\
\hline $\mathbf{T}_{10}$ & 22.13 & 40.64 & 12.15 & 31.47 & 25.13 & 45.65 & 2009 \\
\hline $\mathbf{T}_{11}$ & 21.56 & 39.51 & 11.63 & 30.73 & 24.98 & 45.52 & 1898 \\
\hline $\mathbf{T}_{12}$ & 22.34 & 41.33 & 12.10 & 31.67 & 25.25 & 45.75 & 2074 \\
\hline S.Em. \pm & 0.83 & 1.43 & 0.51 & 0.95 & 0.82 & 1.49 & 102 \\
\hline C.D. at $5 \%$ & 2.36 & 4.07 & 1.47 & 2.71 & 2.34 & 4.25 & 290.22 \\
\hline C.V. \% & 9.04 & 8.33 & 10.13 & 7.30 & 8.02 & 7.95 & 11.86 \\
\hline \multicolumn{8}{|l|}{$\mathbf{Y} \times \mathbf{T}$} \\
\hline S.Em. \pm & 1.17 & 2.02 & 0.73 & 1.35 & 1.16 & 2.11 & 144.00 \\
\hline C.D. at $5 \%$ & NS & NS & NS & NS & NS & NS & NS \\
\hline
\end{tabular}

Data presented in the table are Pooled data of both (2018 and 2019) the years

The increase in plant height might be happened due to favourable influence of nitrogen to produce larger cells with thinner cell walls and its contribution in cell elongation and cell division which assist vegetative growth and ultimately enhanced plant height and dry matter per plant. Similarly increase in number of leaves per plant might be due to the reason that application of phosphorus enhance the various metabolic and physiological processes and thus known as "energy currency" which is subsequently used for vegetative and reproductive growth through photophosphorylation. When discussing about 
different cow based bio-enhancers and botanical treatments, Vermicompost performed better because of it is rich in NPK, different plant hormones and micronutrients, which regulates plant metabolism at cellular level and cast produced by worm feeding on organic substrates are extremely homogenous, fertile material suitable for plant growth.

Vermicompost increases the activities of urease, phosphatase and dehydrogenase, which results in higher metabolic activities. Bajracharya and Rai (2009), Ghanshyam and Jat (2010), Chaitnya et al., (2013), Devi et al., (2013), Rana and Badaliya (2014) and Chaudhary et al., (2015).

\section{Effect on number of nodules per plant}

Data (Table 1) revealed that different treatments exerted their significant effect on number of nodules per plant. Application of Vermicompost @ $4 \mathrm{t} / \mathrm{ha}\left(\mathrm{T}_{8}\right)$ recorded maximum number of nodules per plant (28.77), which was comparable to FYM @ 10 t/ha $\left(\mathrm{T}_{3}\right)$ and 100\% RDF $\left(\mathrm{T}_{2}\right)$. However, the minimum number of nodules per plant (18.08) was registered under the control $\left(\mathrm{T}_{1}\right)$.

Vermicompost increases the population of beneficial microorganisms into the rhizosphere of plant which enhances the nitrognease enzyme responsible for $\mathrm{N}$ fixation of atmospheric $\mathrm{N}$ in legumes. This in turn enriches the $\mathrm{N}$ status of soil, thereby increasing the availability of $\mathrm{N}$.

Vermicompost provides food for the bacterial growth and metabolic activities and presence of higher amount of hormones and balanced $\mathrm{pH}$, maintain the favourable environment results in maximum growth of bacteria present in root nodules might be the reason of maximum number of root nodules. Similar findings have been reported by Das et al., (2002), Bajracharya and Rai (2009), Ghanshyam and Jat (2010), Chaitnya et al., (2013), Devi et al., (2013), Rana and Badaliya (2014) and Chaudhary et al., (2015).

\section{Effect on yield}

Scrutiny (Table 1) of data revealed that different treatments exercised their significant influence on seed yield. The highest seed yield (2509 $\mathrm{kg} / \mathrm{ha}$ ) was noted with an application of $100 \%$ RDF $\left(\mathrm{T}_{2}\right)$, which remained statistically at par with Vermicompost @ 4 t/ha $\left(\mathrm{T}_{8}\right)$, FYM @ 10 t/ha ( $\left.\mathrm{T}_{3}\right)$, Vermicompost @ 2 t/ha + Panchgavya as foliar spray @ 3\% ( $\left.\mathrm{T}_{9}\right)$ and FYM @ 5 t/ha + Panchgavya as foliar spray @ $3 \%$ at 30 and 60 DAS $\left(\mathrm{T}_{4}\right)$. However, significantly the lowest seed yield $(1398 \mathrm{~kg} / \mathrm{ha})$ was registered under control $\left(\mathrm{T}_{1}\right)$. More availability of photosynthates, metabolites and nutrients to the plants helps in development of good reproductive structure, phosphorus is considered as energy-currency, that's why it is essential for the general health and vigour of all plants. In case of organic cultivation vermicompost provides better soil environment, which encouraged proliferation of plant roots, which helped to absorb more water and nutrients from larger area and deeper layers and thus owing to higher availability of nutrients, synthesis of more carbohydrates and their translocation to different plant parts resulted increased vegetative growth including the reproductive structures.

These findings are in conformity with the Das et al., (2002), Jat and Ahlawat (2004), Ghanshyam and Jat (2010), Mycin et al., (2010), Paliwal et al., (2011), Vasoya (2014), Chaudhary et al., (2015) and Khan et al., (2017).

From the above result it can be concluded that adoption of organic farming in soybean crop cultivation, application of Vermicompost @ 4 t/ha might be a good option. Other than alone application of Vermicompost @ 4 t/ha, application of FYM @ 10 t/ha also performed better.

\section{References}

Bajracharya, S. K. and Rai, S. K. 2009. Study on the effects of vermicompost on nodulation and yield of chickpea. Nepal 
Agriculture Research, 9: 49-55.

Chaitnya, T., Padmaja, G., Rao, P. and Chandrashekhar. 2013. Activity of soil urease, dehydrogenase and phosphatase as influenced by integrated nutrient management in tomato (Lycopersicon esculentum L.) grown on alfisol. Crop Research, 45(1-3): 210-2014.

Chaudhary, J. H., Sutaliya, R. and Desai, L. J. 2015. Growth, yield, yield attributes and economics of summer groundnut (Arachis hypogaea L.) as influenced by integrated nutrient management. Journal of Applied and Natural Sciences, 7(1): 369-372.

Devi, K. N., Singh, T. B., Athokpam, S. H., Singh, N. B. and Shamurailatpam, D. 2013. Influence of inorganic, biological and organic manures on nodulation and yield of soybean (Glycine $\max$ L.) and soil properties. Australian Journal of Crop Sciences, 7(9): 1407-1415.

Ghanshyam, R. K. and Jat, R. K. 2010. Productivity and soil fertility as effected by organic manures and inorganic fertilizers in green gram (Vigna radiata) - wheat (Triticum aestivum) system. Journal of Agronomy, 55(1): 16-21.

Gore, N. S. and Shreenivasa, M. N. 2011. Influence of liquid organic manures on growth, nutrient content and yield of tomato (Lycopersicon esculentum Mill.) in the sterilized soil. Karnataka Journal of Agriculture Science, 28(2): 158-167.

Halwankar, G. B., Raut, V. M., Taware, S. P., Patil, V. P. 1992. Production component study in soybean. J. MAU, 17(3): 396-398.

Jat, R. S. and Ahlawat, I. P. S. 2004. Effect of vermicompost biofertilizer and phosphorus on growth, yield and nutrient uptake by gram (Cicer arientinum) and their residual effect on fodder maize (Zea mays). Indian
Journal of Agricultural Sciences, 74(7): 359-361.

Khan V. M., Ahamad, A., Yadav B. L. and Mohammad, I. 2017. Effect of vermicompost and biofertilizers on yield attributes and nutrient content and it's their uptake of cowpea [Vigna unguiculata (L.) Walp.]. International Journal of Current Microbiology and Applied Sciences, 6(6): 1045-1050.

Mycin, T. R., Lenin, M., Selvakumar, G. and Thangadurai, R. 2010. Growth and Nutrient Content Variation of Groundnut Arachis hypogaea L. under Vermicompost Application. Journal of Experimental Sciences, 1(8): 12-16.

Paliwal, D. K., Kushwaha, H. S. and Thakur, H. K. 2011. Performance of soybean [Glycine $\max$ (L.) Merrill]-wheat (Triticum aestivum) cropping system under land configuration, mulching and nutrient management. Indian Journal of Agronomy, 56(4): 334-339.

Pandey, M. K., Gupta, V., Kalha, C. S. and Gupta, D. 2008. Organic farmingPrinciples and practices for progressive agriculture. Green Farming, 1(6): 16-19.

Rana, R. and Badaliya, D. 2014. Effect of integrated nutrient management on seed, quality and nutrient uptake of soybean (Glycine $\max$ L.) under mid hill condition of Himanchal Pradesh. Indian Journal of Agronomy, 59(4): 641-645.

Vasoya, U.J. 2014. Effect of organic manure and bio-fertilizer on growth and yield of direct seeded rabi fennel (Foeniculum vulgare Mill.). M.Sc. (Agri.) Thesis (Unpublished), Junagadh Agricultural University, Junagadh.

\section{How to cite this article:}

Pooja, P. K. Chovatia, R. K. Kathiriya and Khushboo Gupta. 2020. Effect of Cow Based Bioenhancers and Botanicals on Growth and Yield of Soybean (Glycine max L.). Int.J.Curr.Microbiol.App.Sci. 9(09): 324-328. doi: https://doi.org/10.20546/ijcmas.2020.909.041 